КИРИЧЕНКО Т.М.

\title{
ОСНОВНІ ПОЛОЖЕННЯ ЗАГАЛЬНОТЕОРЕТИЧНОЇ ХАРАКТЕРИСТИКИ ІНСТИТУТУ МОРАЛЬНОЇ ШКОДИ
}

У статті викладено основні узагальненні положення, які отримано в результаті здійсненного грунтовного дослідження загальнотеоретичної характеристики інституту моральної шкоди. Наголошено, що актуальність наукового пошуку доводиться тим фактом, що сьогодні під час реформування трудового законодавства потребується особливо зважений підхід до питань моральної шкоди в трудових відносинах, який, своєю чергою, можливий за умови окреслення основних положень із порушеного питання. Визначено, що категорію «моральна шкода» можна розглядати у двох аспектах: соціальному та правовому. Відповідно до соціального аспекту, моральна шкода являє собою шкідливий наслідок порушення усталеної системи принципів, норм, правил поведінки між людьми та ставлення кожного окремого індивіда до суспільства у цілому. У правовому аспекті під немайновою (моральною) шкодою слід розуміти шкоду, завдану внаслідок будь-яких порушень немайнових прав фізичної та юридичної особи. Зроблено висновок, що відшкодування моральної (немайнової) шкоди є важливим інструментом у сфері захисту прав і свобод людини та громадянина. Юридичне забезпечення цього права людини $є$ показником поваги держави до честі та гідності кожної людини, є свідченням того, що людина, іiї права свободи й інтереси $є$ найвищою соціальною цінністю в державі. Закріплення права на компенсацію моральної шкоди дає можливість особі відчувати впевненість у тому, що її права перебувають під постійним захистом держави. Процес розвитку правового інституту моральної шкоди супроводжується збільшенням кола правовідносин, на які поширюється законодавство про компенсацію моральної шкоди, а також кола суб'єктів, котрі наділяються правом на відшкодування моральної (немайнової) шкоди. Підтвердженням цього $є$ досить розширена законодавча база, яка передбачає право на відшкодування моральної (немайнової) шкоди, що вказує на поступове та неухильне вдосконалення законодавства, яке регулює відносини у сфері компенсації моральної (немайнової) шкоди. Значення права людини на компенсацію моральної (немайнової) шкоди складно переоцінити, оскільки його закріплення сприяє формуванню у кожної людини відчуття захищеності, усвідомленню своєї цінності для суспільства та держави, що вказує на розвиток в Україні громадянського суспільства та становлення правової, демократичної держави.

Ключові слова: моральна шкода, інститут, характеристика, теоретичні положення, узагальнення.

The article summarizes the main generalizations that are obtained as a result of a thorough study of the general theoretical characteristics of the Institute of moral harm. It is emphasized that the urgency of the scientific search is proved by the fact that today the reform of the labor legislation requires a particularly balanced approach to the issues of moral harm in labor relations, which in turn is possible provided that the basic provisions on the raised issue are outlined. It has been determined that the category of "moral harm" can be considered in two aspects: social and legal. According to the social aspect, moral harm is a harmful consequence of violation of the established system of principles, norms, rules of behavior between people and the attitude of each individual to society as a whole. In legal terms, non-pecuniary (non-pecuniary) damage should be understood as damage caused as a result of any violation of the non-pecuniary rights of a

( ) КИРИЧЕНКО Т.М. - здобувач кафедри правознавства (Східноукраїнський національний університет імені Володимира Даля) 
natural or legal person. It is concluded that compensation for moral (non-material) harm is an important tool in the field of protection of human and citizen's rights and freedoms. The legal protection of this human right is an indication of the state's respect for each person's honor and dignity, and is a testament to the fact that a person, his or her rights and freedoms and interests are the highest social value in the state. Establishing the right to non-pecuniary damage enables one to feel confident that his or her rights are under the permanent protection of the state. The process of developing a non-pecuniary damage legal institution is accompanied by an increase in the range of legal relationships covered by non-pecuniary damage law, as well as by those entitled to non-pecuniary damage. Confirmation of this is a sufficiently broad legislative framework that provides for the right to compensation for non-pecuniary (non-pecuniary) damage, which indicates a gradual and steady improvement of the legislation governing relations in the sphere of non-pecuniary damage. The importance of the human right to compensate for moral (non-property) harm is difficult to overestimate, since its consolidation contributes to the formation of a sense of security for each person, an awareness of its value to society and the state, which indicates the development of civil society in Ukraine and the establishment of a legal, democratic state.

Key words: moral damage, institute, characteristics, theoretical propositions, generalizations.

Вступ. Інститут моральної шкоди $є$ складовою частиною правової системи будь-якої розвинутої країни і покликаний виконувати досить важливі функції щодо захисту порушених прав осіб. Сьогодні він посідає чільне місце у правових системах багатьох країн світу [1, с. 1]. Інститут моральної шкоди, незважаючи його на успішний розвиток та існування в цивілізованих країнах світу, є відносно новим правовим інститутом для вітчизняної системи права, що пояснюється перебуванням України в складі СРСР, правова доктрина якого заперечувала ідею відшкодування моральної шкоди та всіляко стримувала ії втілення у законодавство. І лише 3 проголошенням незалежності в Україні інститут моральної шкоди набув ключового значення у сфері відносин щодо відшкодування шкоди.

Історія розвитку інституту моральної шкоди, його основні характерні ознаки та особливості були предметом дослідження наукових робіт багатьох українських та російських учених. Так, цим питанням присвятили свої наукові праці В. Гончарук, Е.В. Горян, О.В. Дзера, А.І. Дрішлюк, Г.В. Єрьоменко, О.М. Ерделевський, Я.О. Завоюра, Ю.О. Заіка, Т. Карнаух, Л.І. Криушенко, В.В. Луць, І. Майстер, В.П. Паліюк, Н.Л. Полішко, П.М. Рабінович, Р.О. Стефанчук, А.Т. Табунщіков та ін. Однак комплексного та грунтовного дослідження моральної шкоди в трудовому праві доки не було здійснено. Разом із тим для того щоб здійснити таке дослідження, все ж спочатку потребується визначення основних положень щодо інституту моральної шкоди.

Провівши грунтовне дослідження у цьому напрямі, що можна спостерігати і в інших наших наукових публікаціях, у даній науковій статті викладемо основні результати нашого дослідження. Вони здебільшого мають форму висновків та узагальнень, але це не зменшує їхньої корисності для сучасної науки, а, навпаки, зумовлює необхідність у ознайомленні з ними наукового співтовариства.

Постановка завдання. Метою статті є ознайомлення наукового світу з основними висновками здійсненного нами грунтовного дослідження щодо загальнотеоретичної характеристики інституту моральної шкоди, яке має обсяг в десятки разів більший за наукову статтю, а тому не може бути представлений у межах цієї роботи. Актуальність наукового пошуку за вибраним напрямом доводиться тим фактом, що сьогодні під час реформування трудового законодавства необхідний особливо зважений підхід до питань моральної шкоди в трудових відносинах, який, своєю чергою, можливий за умови окреслення основних положень із порушеного питання. Доцільність такої наукової статті аргументується тим, що привернення уваги до цього питання викличе дискусію та відповіді серед науковців щодо викладених основних положень, що, вочевидь, дасть змогу у разі необхідності скорегувати власні висновки та вдосконалити в майбутньому пропозиції щодо змін у проєкт ТК України. Таким чином, сумісна наукова робота сприятиме вдосконаленню як трудового законодавства, так і теоретичних положень трудового права.

Результати дослідження. Вивчивши та проаналізувавши наукові доробки перелічених вище авторів та особливу увагу приділивши працям О.Т. Табунщікова, В.П. Паліюка, С.О. Бєляцькіна, К.І. Голубєва, О.М. Ерделевського, М.С. Малеїна, С.А. Міхно [2-8], а також здійснивши ре- 
тельний аналіз норм чинного законодавства України, ми дійшли таких основних висновків щодо загальнотеоретичної характеристики інституту моральної шкоди:

1. Інститут моральної шкоди має довгий та поступовий шлях розвитку і становлення, який уходить своїми коріннями в стародавні часи. Пам'ятки стародавнього законодавства, такі як Закони XII таблиць та Закони Хаммурапі, що частково збереглися до наших часів, зокрема, свідчать про зародження цього правового інституту. На етнічній території сучасної України виникнення прототипу інституту моральної шкоди пов'язується з X ст. У ті часи була запроваджена сплата грошового еквіваленту за спричинену немайнову шкоду. При цьому метою такого відшкодування було витіснення кровної помсти. У подальшому в різних редакціях «Руської правди» передбачалися норми про відшкодування шкоди за «образу», що в сучасному розумінні було аналогом спричинення моральної, або немайнової, шкоди.

2. Положення про відшкодування шкоди за образу передбачалися в Судебнику 1497 року та Судебнику 1550 року. Ці джерела права передбачали положення про відшкодування завданої немайнової шкоди, що вказує на еволюцію інституту моральної шкоди. На продовження розвитку інституту моральної шкоди вказує закріплення норм, які передбачали відповідальність за образу та безчестя у Соборному уложенні царя Олексія Михайловича 1649 року, Військовому уставі 1716 року, Морському уставі 1720 року, Збірнику законів Малоросійських прав 1743 року та Зводі законів Російської імперії.

3. У другій половині XIX ст. з'явилися кілька правових норм, які могли стати підставою для вимоги щодо відшкодування моральної (у дореволюційної правовій традиції) шкоди. Положення Зводу законів Російської імперії вказують на існування загальних норм, котрі можна вважати окремими нагадуваннями про існування інституту моральної шкоди, який охоплював певні випадки завдання моральної шкоди. Водночас законодавство тих часів прямих указівок на можливість відшкодування моральної шкоди не містило.

4. На початку XX ст. вже склалося досить чітке уявлення про поняття «моральна шкода», під якою розуміли шкоду, страждання фізичні та моральні, завдані потерпілому неправомірною діяльністю делінквента (правопорушника), яка підлягала відшкодуванню.

5. Історичним кроком у розвитку інституту моральної шкоди став проєкт закону Російської імперії «Про зобов'язальне право», який передбачав відшкодування моральної шкоди в разі нанесення тілесних ушкоджень, незаконного позбавлення волі, невиконання боржником зобов'язань за умови наявності умислу або необережності. Однак революційні події 1917 року унеможливили прийняття цього законодавчого акту. Доктрина радянської держави не припускала можливості відшкодування моральної шкоди. Разом із цим окремі положення законодавства нової держави передбачали можливість пред'явлення вимог щодо відшкодування моральної шкоди. Проте судові органи новоствореної держави позови про відшкодування немайнової шкоди шляхом стягнення грошових сум не задовольняли.

6. Тривалий час радянське законодавство заперечувало можливість існування інституту моральної шкоди з огляду на іï буржуазну сутність, яка є неприйнятною для соціалістичної правосвідомості. Позиція правової доктрині Радянського Союзу не допускала визначення людини як окремого індивіда, особа не розглядалася у відриві від суспільства та держави. Тому першочергове зазначення мали саме державні і суспільні інтереси, тоді як дотримання прав людини першого покоління зводилося до формального закріплення у законодавстві. Набрання чинності у 1961 році Кримінально-процесуального кодексу, який містив у собі термін «моральна шкода», стало переломним для розвитку інституту моральної шкоди у Радянському Союзі. Протягом наступних тридцяти років поняття «моральна шкода» повільно проникало в радянське законодавство.

7. Із проголошенням незалежності в Україні розпочалася робота зі створення національної правової системи, в якій особливе місце посідає інститут моральної шкоди. Цей правовий інститут продовжує свій розвиток та вдосконалення. Сьогодні існує велика кількість законодавчих актів, які містять у собі право фізичної й юридичної особи на відшкодування моральної шкоди. Отже, збільшується коло правовідносин, на які поширюється законодавство про відшкодування моральної шкоди. Така тенденція свідчить про необхідність підвищення ступеню захисту немайнових прав фізичних та юридичних осіб.

8. Сьогодні право на відшкодування моральної шкоди передбачається великою кількістю нормативно-правових актів, однак законодавець у жодному з них не наводить уніфікованого поняття «моральна шкода», обмежившись визначенням найбільш загальних характеристик моральної шкоди. Юридична наука також не випрацювала однозначного підходу до трактування моральної шкоди. 
9. Категорію «моральна шкода» можна розглядати у двох аспектах: соціальному та правовому. Відповідно до соціального аспекту, моральна шкода являє собою шкідливий наслідок порушення усталеної системи принципів, норм, правил поведінки між людьми та ставлення кожного окремого індивіду до суспільства у цілому. У правовому аспекті під немайновою (моральною) шкодою слід розуміти шкоду, завдану внаслідок будь-яких порушень немайнових прав фізичної та юридичної особи.

10. Зміст немайнової шкоди юридичній особі полягає у шкоді, яка завдана протиправними діями (бездіяльністю) фізичних та юридичних осіб, що порушують немайнові права юридичної особи, які можуть їй належати й які охороняються чинним законодавством України, зокрема якими є недоторканність, ділова репутація юридичної особи, таємниця її кореспонденції, інформація та інші особисті немайнові права. Зміст моральної шкоди фізичній особи полягає у фізичних та моральних стражданнях, які вона зазнала у зв'язку з: ушкодженням іiї здоров'я; вчиненням протиправних дій щодо неї або членів її родини; приниженням їі честі та гідності; порушенням iі майнових прав; іншими негативними явищами.

11. Під моральними стражданнями фізичної особи слід розуміти негативні, несприятливі емоції, які відчуває людина в результаті протиправного порушення іiі прав. Фізичними стражданнями є будь-які больові відчуття, що стали наслідком порушення здоров'я людини, тілесного ушкодження або іншого функціонального розладу в результаті порушення прав людини. Поняття «страждання» доцільно розглядати як реакцію фізичної особи на неправомірні дії заподіювача шкоди, внаслідок яких їй завдано фізичного або морального болю. Іншими негативними явищами, які заподіяні фізичній чи юридичній особі незаконними діями або бездіяльністю інших осіб, $\epsilon$ результати будь-якого протиправного впливу на особу, що порушує їі індивідуальну сферу, внаслідок якого особі спричиняється шкода немайнового характеру.

12. Використання поняття «моральна шкода» стосовно юридичних осіб не відповідає змісту цього поняття, не узгоджується із загальновизнаними уявленнями про юридичну особу як штучно створеного учасника правових відносин, якому не властиво переживати емоційні відчуття. Водночас юридична особа наділена правом на відшкодування шкоди, завданої внаслідок порушення немайнових прав, що вказує на доцільність зміни термінології та використання замість поняття «маральна шкода» категорії «немайнова шкода». Такий підхід найбільш повно відображає зміст досліджуваної категорії, охоплює усіх суб'єктів, котрі мають право на відшкодування моральної (немайнової) шкоди, та дасть змогу усунути неоднозначні підходи до трактування поняття, яким охоплюються втрати немайнового характеру, що виникли внаслідок моральних, фізичних страждань або приниження честі гідності та ділової репутації, спричинених фізичній або юридичній особі.

13. У цивільному праві виокремлюють шкоду, яка виникла внаслідок делікту або недоговірних зобов'язань, та шкоду, що стала наслідком порушення договірного зобов'язання. Принципова відмінність даних видів шкоди полягає у тому, що деліктна шкода відшкодовується в разі протиправного порушення майнових та особистих немайнових права, а договірна - за порушення договірних зобов'язань. До відмінних рис також слід віднести те, що правопорушником може виступати будь-яка особа, у договірних - лише ті особи, між якими укладено відповідний договір. Моральна (немайнова) шкода не може бути наслідком порушення договірних зобов'язань та може носити лише деліктний характер, оскільки прояви цієї шкоди, визначені цивільним законодавством, у будь-якому разі не можуть випливати з договірних правовідносин. Отже, не можуть поставати елементами договірних зобов'язань, тому моральна (немайнова) шкода є наслідком делікту.

14. Відшкодування моральної (немайнової) шкоди може мати як матеріальний, так і нематеріальний характер. Моральну (немайнову) від майнової шкоди відрізняє те, що остання завжди має економічний зміст, оскільки ці втрати мають матеріальну форму та проявляються у нанесених збитках та в інших майнових втратах.

15. Майнова шкода має вартісне визначення, яке може бути виміряне та виражене у грошових коштах, що дає змогу досить точно обчислити ії. Отже, майнова шкода знаходиться у матеріальній площині, яка відшкодовується, грунтуючись на засадах еквівалентності. Моральна (немайнова) шкода знаходитися у площині нематеріальній, оскільки завдається життю, здоров'ю, честі, гідності фізичної особи та немайновим правам юридичної особи, які становлять немайнові блага цих осіб.

16. До характерних ознак моральної (немайнової) шкоди слід віднести: деліктний характер; незворотність наслідків, спричинених унаслідок порушення немайнових прав; моральна (немайнова) шкода має нематеріальний характер, її неможливо виміряти грошима або будь-яким 
іншим майновим способом, оскільки вона знаходиться в нематеріальній площині; моральна (немайнова) шкода перебуває в нерозривному зв'язку з конкретною особою, якій спричинена ця шкода, оскільки шкода спричиняється благам, що є невід'ємними від особи.

17. Визначені чинним законодавством критерії відшкодування моральної (немайнової) шкоди $є$ оціночними поняттями та не дають можливості для адекватного відшкодування завданої шкоди з метою згадування іiї несприятливих наслідків. Разом із цим оціночні поняття, які використовуються для визначення розмірів відшкодування моральної (немайнової) шкоди, конкретизуються в процесі правозастосування у кожному окремому випадку, що забезпечує можливість індивідуального підходу до кожного суспільного відношення.

18. Призначення законодавчих положень про компенсацію моральної шкоди полягає у зменшенні, згладжуванні негативних наслідків, викликаних протиправним порушенням особистих немайнових, тоді як відшкодування майнової шкоди полягає у відновленні порушеного майнового блага.

19. Моральну (немайнову) шкоду слід розглядати як пряму (чисту) та похідну. Пряма шкода - це шкода, завдана внаслідок приниження честі, гідності та ділової репутації, яка може бути спричинена як фізичній, так і юридичній особі.

20. Похідна моральна (немайнова) шкода являє собою наслідки спричинення шкоди, яка має наслідком фізичні або моральні страждання. Грунтуючись на аналізі цивільного законодавства, похідну шкоду можна класифікувати на: 1) моральну (немайнову) шкоду, спричинену безпосередньо особі у результаті спричинення ій каліцтва або іншого ушкодження здоров'я; 2) моральну (немайнову) шкоду, завдану особі внаслідок учинення протиправних дій відносно ії неї, членів її сім’ї або близьких родичів; 3 ) моральну (немайнову) шкоду, завдану особі порушенням іiі майнових прав.

Висновки. Відшкодування моральної (немайнової) шкоди є важливим інструментом у сфері захисту прав і свобод людини та громадянина. Юридичне забезпечення цього права людини є показником поваги держави до честі та гідності кожної людини, є свідченням того, що людина, іiі права свободи та інтереси є найвищою соціальною цінністю в державі. Закріплення права на компенсацію моральної шкоди дає можливість особі відчувати впевненість у тому, що її права перебувають під постійним захистом держави. Процес розвитку правового інституту моральної шкоди супроводжується збільшенням кола правовідносин, на які поширюється законодавство про компенсацію моральної шкоди, а також кола суб' єктів, котрі наділяються правом на відшкодування моральної (немайнової) шкоди. Підтвердженням цього є досить розширена законодавча база, яка передбачає право на відшкодування моральної (немайнової) шкоди, що вказує на поступове та неухильне вдосконалення законодавства, яке регулює відносини у сфері компенсації моральної (немайнової) шкоди. Значення права людини на компенсацію моральної (немайнової) шкоди складно переоцінити, оскільки його закріплення сприяє формуванню у кожної людини відчуття захищеності, усвідомленню своєї цінності для суспільства та держави, що вказує на розвиток в Україні громадянського суспільства та становлення правової, демократичної держави.

Отже, сподіваємося на привернення уваги до питань моральної шкоди не тільки фахівців трудового права, а й інших галузей права, що дасть змогу у сумісній співпраці виробити більш досконалі теоретичні підходи до розуміння сутності та змісту моральної шкоди у цілому та в трудових правовідносинах зокрема.

\section{Список використаних джерел:}

1. Горян Е.В., Завоюра Я.О. Відшкодування моральної шкоди при здійсненні міжнародних повітряних перевезень. Часопис Академії адвокатури України. 2012. № 14. С. 1-6.

2. Табунщиков А.Т. Компенсация морального вреда в гражданском законодательстве Российской Федерации : автореф. дис. ... к.ю.н. : 12.00.03. - Гражданское право; Предпринимательское право; Семейное право; Международное частное право ; Санкт-Петербургский университет. Санкт-Петербург, 2005. 26 с.

3. Палиюк В.П. Моральный (неимущественный) вред. Київ : Право, 1999. 232 с. 2005. $64 \mathrm{c}$.

4. Беляцкин С.А. Возмещение морального (неимущественного) вреда. Москва : Городец,

5. Голубев К.И., Нарижний С.В. Компенсация материального вреда как способ защиты неимущественных благ личности. Санкт-Петербург : Юридический центр «Пресс», 2004. 327 с.

6. Эрделевский А.М. Компенсация морального вреда в России и за рубежом. Москва : ФОРУМ-ИНФРА-М, 1997. 240 с. 
7. Малеин Н.С. Возмещение вреда, приченённого личности. Москва : Юридическая литеpamypa, $1965.230 \mathrm{c}$.

8. Михно Е.А. Компенсация морального вреда во внедоговорных обязательствах : автореф. дис. ... к.ю.н. : 12.00 .03 - Гражданское право; Семейное право; Гражданский процесс; Международное частное право ; Санкт-Петербургский государственный университет. Санкт-Петербург, 1998. 35 с.

УДК 341.9

DOI https://doi.org/10.32844/2618-1258.2019.5-2.10

ЛУКАНЬ М.О.

\section{КОНФЛІКТ ОСНОВНИХ ПРАВ ЛЮДИНИ 3 ПРАВОМ ІНТЕЛЕКТУАЛЬНОЇ ВЛАСНОСТІ: ЄВРОПЕЙСЬКИЙ ДОСВІД}

Статтю присвячено дослідженню конфлікту фундаментальних прав людини, гарантованих Хартією основних прав Європейського Союзу та Європейською конвенцією про захист прав людини і основних свобод із правом на захист інтелектуальної власності. В статті розглянуті підходи суду Європейського Союзу до вирішення таких зіткнень. Наведено міркування про важливість вирішення зазначених конфліктів заради справедливого балансу приватних прав та інтересів кожної людини й економічного добробуту людства.

Приділено увагу випадкам протистояння права на захист особистих (персональних) даних, права на повагу до приватного та сімейного життя, права на банківську таємницю та права на повагу до інтелектуальної власності. Несправедливий баланс між правом на повагу та захистом інтелектуальної власності та правом на захист персональних даних призводить до зневаги інтелектуальних здобутків правовласників та ускладнює притягнення до відповідальності порушників.

Проаналізовано узгодження положень Хартії основних прав Європейського Союзу та Європейської конвенції про захист прав людини і основних свобод, Регламенту (СС) 2016/679 Європейського Парламенту та Ради від 27 квітня 2016 року про захист фізичних осіб у зв'язку з опрацюванням персональних даних, про вільний рух таких даних і про скасування Директиви 95/46/СС («Загальний регламент про захист даних» (General Data Protection Regulation - GDPR), Директиви 95/46/ ЄС від 24 жовтня 1995 року про захист окремих служб у відносинах з обробкою фізичних даних і про вільне переміщення цих даних, Директиви 2002/58/€С від 12 липня 2002 року про конфіденційність та електронні комунікації та основного документа, які стосується захисту прав інтелектуальної власності на європейському просторі, - Директиви № 2004/48/ЄС Європейського парламенту і Ради ЄС про забезпечення прав на інтелектуальну власність.

Сформовано висновки відповідно до підходів, які базуються на базових принципах ЄС та практиці суду Європейського Союзу, якими слід керуватися при виникненні конфліктів основних прав і права інтелектуальної власності з метою забезпечення справедливого балансу.

Ключові слова: захист інтелектуальної власності, основні права, захист персональних даних, суд Європейського Союзу, «Загальний регламент про захист даних».

The article is devoted to the study of the conflict of fundamental human rights guaranteed by the Charter of Fundamental Rights of the European Union and the European Convention for the Protection of Human Rights and Fundamental Freedoms with

(C) ЛУКАНЬ М.О. - аспірант кафедри міжнародного приватного права та порівняльного правознавства (Національний юридичний університет імені Ярослава Мудрого) 